\title{
System kontroli wewnętrznej w bankach a instytucja kontroli zarządczej w jednostkach sektora finansów publicznych
}

\section{Wprowadzenie}

"Zarządzanie ryzykiem” czy "kontrola wewnętrzna” to pojęcia od dawna znane i stosowane w prawie bankowym. Z kolei kontrola zarządcza jako instytucja prawna (w sensie przedmiotowym) pojawiła się również w ustawie o finansach publicznych z 2009 r. Obydwie te instytucje, a więc system kontroli wewnętrznej jako instytucja (w sensie przedmiotowym) prawa bankowego i kontrola zarządcza w prawie finansów publicznych wykazują znaczące regulacyjne podobieństwa. Są zarazem instytucjami kontroli i - jako odnoszące się w pierwszym przypadku do prawa bankowego, a w drugim przypadku do prawa finansów publicznych - muszą uwzględniać specyfikę obszaru normatywnego, z którym są związane, choć przedmiot ich kontroli wykazuje podobieństwa. W obydwu też przypadkach chodzi o kontrolę prowadzoną wewnątrz banku (kontrola wewnętrzna) czy wewnątrz jednostek sektora finansów publicznych (kontrola zarządcza).

W artykule zestawiono, w celach porównawczych, dwie instytucje odnoszące się: w pierwszym przypadku do prawa finansów publicznych (kontroli zarządczej), a w drugim - do instytucji prawa bankowego (system kontroli wewnętrznej w bankach). Mogłoby się wydawać, że wskazane instytucje, w dodatku pochodzące $\mathrm{z}$ dwóch różnych obszarów tematycznych, nie mogą wykazywać zbyt wielu podobieństw regulacyjnych. Jednak dogmatycznoprawna analiza tych instytucji daje podstawy i argumenty do wysunięcia tezy o ich 
regulacyjnym podobieństwie i rodzi pytania o podobieństwo funkcji, jakie mogą one realizować w prawie bankowym i w prawie finansów publicznych, z zastrzeżeniem specyfiki obszarów, do których się odnoszą. Takie twierdzenie natomiast uprawnia w dalszej konsekwencji do formułowania uwag, że w systemie finansów publicznych z powodzeniem wykorzystywane są elementy konstrukcji normatywnych bardziej znanych i właściwych prawu rynku finansowego, „sektorowi rynkowemu", zapewne dla osiągnięcia takich celów i funkcji, które w regulowanym obszarze finansów publicznych łatwiej i adekwatniej osiągnąć można za pomocą instytucji naturalnie związanych z "sektorem rynkowym". Zauważmy, że może to w przyszłości wyznaczyć interesujące teoretycznie i praktycznie pytania badawcze dotyczące możliwości zaadaptowania do prawa finansów publicznych innych jeszcze elementów konstrukcyjnych instytucji właściwych dla prawa bankowego czy, szerzej, prawa rynku finansowego. W szczególności chodzi tutaj o realizację podobnie określonych celów (rzecz jasna, z uwzględnieniem specyfiki obydwu obszarów) w zakresie zarządzania ryzykiem, które oczywiście inaczej pojmowane jest na gruncie prawa bankowego (mikroostrożnościowo, a ostatnio również makroostrożnościowo - co daje też wspólną z finansami publicznymi, kolejną płaszczyznę rozważań teoretyczno-praktycznych odnoszących się do nadzoru makroostrożnościowego jako przeciwdziałającego ryzyku systemowemu), inaczej zaś w prawie finansów publicznych.

Od strony teorii regulacji uważać można jednak, że porównania takie identyfikują zasadność regulacyjnego ujednolicania pojęć, celów i funkcji, a w ten sposób mogą przyczynić się do wieloaspektowego badania funkcji realizowanych przez instytucje prawne (w sensie przedmiotowym) działałające w systemie prawa. Taka właśnie konstatacja dała asumpt do podjęcia przedstawianej problematyki.

Przedmiotem niniejszego opracowania jest zatem analiza dwóch wybranych instytucji kontroli zarządczej w finansach publicznych i systemu kontroli wewnętrznej w bankach jako przykładów instytucji odnotowujących regulacyjne i funkcjonalne podobieństwa w badanych dwóch obszarach prawa. Inspiracją do podjęcia analiz stała się chęć udzielenia odpowiedzi na pytanie o istotę kontroli wewnętrznej w ramach finansów publicznych (kontroli zarządczej), która wykazuje, choćby w zakresie celów i kryteriów kontroli, wiele elementów właściwych instytucji kontroli w prawie bankowym, czyli systemu kontroli wewnętrznej funkcjonującej w bankach. Trzeba bowiem zauważyć, że zarówno w ustawie o finansach 
publicznych ${ }^{1}$, jak i w ustawie Prawo bankowe ${ }^{2}$ mowa w przepisach o kontroli, a w obydwu przypadkach jest to kontrola wewnętrzna, i w obydwu przypadkach kontrola ta musi być uznana za kontrolę wiązaną ze stanem i zjawiskami procesów gospodarowania - w pierwszym przypadku odnosi się ona do środków publicznych, w drugim zaś kontrolą objęto m.in. system wewnętrznej kontroli zarządzania ryzykiem finansowym w działalności banków. Charakterystyczne zarówno dla systemu kontroli wewnętrznej, jak i zarządczej, jest jednak ich bardzo szerokie rozumienie, wykraczające poza klasyczne pojęcie kontroli, a bardziej umiejscowione w procesach zarządczych ${ }^{3}$. Celem artykułu jest również udzielenie odpowiedzi na pytanie o sposób rozumienia pojęcia "system kontroli wewnętrznej" na gruncie ustawy Prawo bankowe i "kontrola zarządcza” na gruncie ustawy o finansach publicznych, ich istotę oraz spójność rozumienia wskazywanych celów i kryteriów kontroli we wskazanych obszarach. Zamierzeniem badawczym przedstawianego opracowania jest jednak także ukazanie różnic między kontrolą zarządczą i systemem kontroli wewnętrznej, które ze względu na specyfikę kontrolowanych spraw finansowych wykazują odrębności, a tym samym pozwalają na przedstawienie funkcji kontrolnych związanych ze specyficznymi potrzebami poszczególnych obszarów prawa.

Metodą badawcza, która leży u podstaw prowadzonych analiz, jest metoda dogmatycznoprawna, a zakresem analiz i formułowanych ocen objęto postanowienia art. 68-71 u.f.p. oraz art. 9a-f pr. bank. Metoda dogmatycznoprawna została uzupełniona o metodę prawnoporównawczą w zakresie zestawienia z punktu widzenia kształtu regulacyjnego instytucji kontroli zarządczej i systemu kontroli wewnętrznej.

\section{System kontroli wewnętrznej w świetle ustawy Prawo bankowe}

Instytucja kontroli wewnętrznej, a następnie instytucja zarządzania ryzykiem zostały uregulowane stopniowo w art. 9-9f pr. bank. na

${ }^{1}$ Ustawa z dnia 27 VIII 2009 r. o finansach publicznych (tekst jedn. Dz.U. 2017, poz. 2077 ze zm.), dalej „u.f.p.”.

${ }^{2}$ Ustawa z dnia 29 VIII 1997 r. Prawo bankowe (tekst jedn. Dz.U. 2017, poz. 1876 ze zm. ), dalej „pr. bank.” lub „Prawo bankowe”.

${ }^{3} \mathrm{Na}$ temat specyfiki pojęcia "kontrola zarządcza” zob. m.in. I. Rosiek, System kontroli zarzadczej w jednostkach samorządu terytorialnego - zagadnienia ogólne, LEX/el. 2017, komentarz praktyczny. 
przestrzeni lat 1997-2017. Historia i ewolucja postanowień dotyczących kontroli wewnętrznej jest bardzo bogata. W ustawie Prawo bankowe już w 1997 r. obowiązywał art. 9 w brzmieniu: „W bankach działa kontrola wewnętrzna, która sprawdza legalność i prawidłowość działalności prowadzonej przez bank oraz prawidłowość i rzetelność składanych sprawozdań i informacji". Z kolei w nowelizacji ustawy Prawo bankowe z dnia 1 kwietnia 2004 r. ${ }^{4}$ (poprzez dodanie art. 9c) wprowadzono obowiązek powołania w bankach komórki audytu wewnętrznego, która klasyfikowana była i jest jako nadzorcza norma ostrożnościowa o charakterze jakościowym, będącej jednym ze standardów unijnych ${ }^{5}$. Nowelizacja Prawa bankowego z dnia 26 stycznia 2007 r., związana z wejściem w życie dyrektywy 2006/48/WE, wywołała dalsze zmiany postanowień analizowanych przepisów, a w sposób szczególny uwzględniono wówczas, że w ramach systemu zarządzania w banku funkcjonuje co najmniej system zarządzania ryzykiem i system kontroli wewnętrznej ${ }^{6}$.

Trzeba również zauważyć, rekonstruując wzorzec normatywny systemu kontroli wewnętrznej w bankach, że oprócz przepisów ustawowych wzorzec ten był i jest dookreślany odpowiednimi rekomendacjami organu nadzoru finansowego, które stanowią źródło bankowych norm ostrożnościowych, niebędących normami prawnymi. Postanowienia rekomendacji znajdowały i nadal znajdują swoje odzwierciedlenie $\mathrm{w}$ aktach prawa powszechnie obowiązującego. Jest to związane $\mathrm{z}$ dokonującym się od dłuższego czasu procesem normatywizacji rekomendacji. Warto dodać, że postanowienia rekomendacji H dotyczącej kontroli wewnętrznej w bankach, jak wskazywała wielokrotnie Komisja Nadzoru Finansowego, uszczegóławiały, czy też konkretyzowały przepisy dotyczące funkcjonowania systemu kontroli wewnętrznej określone w ustawie z dnia 29 sierpnia 1997 r. - Prawo bankowe oraz w uchwale nr 383/2008 Komisji Nadzoru Finansowego z dnia 17 grudnia 2008 r. w sprawie szczegółowych zasad funkcjonowania systemu zarządzania ryzykiem i systemu kontroli wewnętrznej oraz szczegółowych warunków szacowania przez banki kapitału wewnętrznego i dokonywania przeglądów procesu szacowania i utrzymywania kapitału wewnętrznego ${ }^{7}$.

${ }^{4}$ Dz.U. 2004 Nr 91, poz. 870.

${ }^{5}$ E. Fojcik-Mastalska, Komentarz do art. 9 ustawy Prawo bankowe, w: Prawo bankowe. Komentarz, pod red. E. Fojcik-Mastalskiej, wyd. 5, LexisNexis 2007/el.

${ }^{6}$ Dz.U. $2007 \mathrm{Nr}$ 42, poz. 271.

${ }^{7}$ Zob. Wstęp do Rekomendacji H z 2011 r., s. 1, https://www.knf.gov.pl/knf/pl/ komponenty/img/Rekomendacja_H_2011_26995.pdf (dostęp: 29 VII 2018). 
Geneza regulacji kontroli wewnętrznej w banku, a następnie systemu kontroli wewnętrznej w banku obejmowała, po pierwsze, rekomendację H Komisji Nadzoru Bankowego dotyczącą kontroli wewnętrznej w banku z 1999 r., zaktualizowaną w 2002 r., i po drugie, rekomendację H Komisji Nadzoru Finansowego z 2011 r. dotyczącą systemu kontroli wewnętrznej w bankach ${ }^{8}$ oraz obecnie rekomendację H Komisji Nadzoru Finansowego z kwietnia 2017 r., dotyczącą systemu kontroli wewnętrznej w bankach ${ }^{9}$, która stanowi zbiór dobrych praktyk w zakresie systemu kontroli wewnętrznej w bankach. Jest ona nie tylko zgodna z ustawą Prawo bankowe i Rozporządzeniem Ministra Finansów i Rozwoju z dnia 6 marca 2017 r. w sprawie systemu zarządzania ryzykiem i systemu kontroli wewnętrznej, polityki wynagrodzeń oraz szczegółowego sposobu szacowania kapitału wewnętrznego w bankach $2017 \mathrm{r}^{10}{ }^{10}$, ale również uwzględnia krajowe i unijne standardy związane z systemem kontroli wewnętrznej. Do standardów tych zalicza się zwłaszcza: wytyczne Europejskiego Urzędu Nadzoru Bankowego z września 2011 r., w sprawie zarządzania wewnętrznego (Guidelines on Internal Governance, GL44)11; Wytyczne Bazylejskiego Komitetu ds. Nadzoru Bankowego: (a) Corporate governance principles for banks z lipca $2015 \mathrm{r} .{ }^{12}$, (b) The internal audit function in banks z czerwca 2012 r. $^{13}$, (c) Compliance and the compliance function in banks z kwietnia 2005 r. ${ }^{14}$; Międzynarodowe standardy praktyki zawodowej audytu wewnętrznego wydane przez Instytut Audytorów Wewnętrznych z 2016 r. ${ }^{15}$ czy Dobre Praktyki Spółek Notowanych na GPW $2016^{16}$.

${ }^{8}$ Rekomendacja H z 2011 r. stanowi nowelizację rekomendacji H z 1999 r., zaktualizowanej w 2002 r., Dz.Urz. KNF z 2011 r., poz. 40, https://www.knf.gov.pl/knf/pl/ komponenty/img/Rekomendacja_H_2011_26995.pdf (dostęp: 29 VII 2018).

${ }_{9}^{9}$ Rekomendacja H z 2017 r. dotycząca systemu kontroli wewnętrznej w bankach, Dz.Urz. KNF z 2017 r., poz. 7, https://www.knf.gov.pl/knf/pl/komponenty/img/ knf_170534_Rekomendacja_H_2017_50303.pdf (dostęp: 29 VII 2018).

${ }^{10}$ Rozporządzenie Ministra Finansów i Rozwoju z dnia 6 marca 2017 r. w sprawie systemu zarządzania ryzykiem i systemu kontroli wewnętrznej, polityki wynagrodzeń oraz szczegółowego sposobu szacowania kapitału wewnętrznego w bankach (Dz.U. 2017, poz. 637), dalej „rozporządzenie MF z 2017 r.”.

11 Szerzej w sprawie Wytycznych Europejskiego Urzędu Nadzoru Bankowego z $2011 \mathrm{r}$. zob.https://www.eba.europa.eu/documents/10180/103861/EBA_2012_00210000_PL_ COR.pdf (dostęp: 29 VIII 2018).

${ }^{12} \mathrm{Na}$ ten temat zob. https://www.bis.org/publ/bcbs294.pdf (dostęp: 29 VIII 2018).

${ }^{13}$ https://www.bis.org/publ/bcbs223.pdf (dostęp: 29 VIII 2018).

${ }^{14}$ https://www.bis.org/publ/bcbs113.pdf (dostęp: 29 VIII 2018).

${ }^{15} \mathrm{http}: / /$ www.mf.gov.pl/c/document_library/get_file?uuid=e3be2ca0-c939-48a5-88fb-8ca2112b3848\&groupId=764034 (dostęp: 28 VII 2018).

${ }^{16}$ https://www.gpw.pl/pub/GPW/files/PDF/GPW_1015_17_DOBRE_PRAKTYKI_ v2.pdf (dostęp: 28 VII 2018). 
W 2017 roku na podstawie art. 9f pr. bank. Minister Rozwoju i Finansów, jak już wskazano powyżej, wydał rozporządzenie w sprawie systemu zarządzania ryzykiem i systemu kontroli wewnętrznej, polityki wynagrodzeń oraz szczegółowego sposobu szacowania kapitału wewnętrznego w bankach. Na mocy tego rozporządzenia, do którego dostosowano zalecenia rekomendacji $\mathrm{H}$ z 2017 r., wykonano nie tylko postanowienia $z$ art. $9 \mathrm{f}$ pr. bank., ale także odnośne postanowienia $z$ regulacji $\mathrm{CRR}^{17} / \mathrm{CRD} \mathrm{IV}^{18}$. Warto zarazem wskazać, że stopniowa ewolucja systemu wewnętrznego zarządzania w banku, obejmująca co najmniej system zarządzania ryzykiem oraz system kontroli wewnętrznej, podlegała rozwojowi, czerpiąc zarówno z wzorców prawa UE, jak i z prawa krajowego, obecnie rozszerzając swój zakres również na instytucję whistleblowing, czyli procedury anonimowego zgłaszania wskazanemu członkowi zarządu, a w szczególnych przypadkach radzie nadzorczej banku, naruszeń prawa oraz obowiązujących w banku procedur i standardów etycznych (zgodnie z art. 9 ust. 2a pr. bank.), a także na politykę wynagrodzeń $\mathrm{w}$ bankach w zakresie wyeliminowania negatywnego wpływu systemów wynagrodzeń na zarządzanie ryzykiem. Zgodnie bowiem z art. 9ca ust. 1 pr. bank. bank jest obowiązany sporządzić i stosować politykę wynagrodzeń dla poszczególnych kategorii osób, których działalność zawodowa ma istotny wpływ na profil ryzyka banku, obejmującą wynagrodzenia i uznaniowe świadczenia emerytalne w rozumieniu art. 4 ust. 1 pkt 73 rozporządzenia $\mathrm{nr}$ 575/2013. Z kolei monitorowanie tendencji i praktyk w zakresie polityki wynagrodzeń stosowanej przez banki należy do Komisji Nadzoru Finansowego (KNF), która gromadzi i analizuje informacje publikowane przez banki zgodnie z art. 450 ust. 1 lit. g-i rozporządzenia nr 575/2013. Polityka wynagrodzeń, zwłaszcza po wejściu w życie regulacji CRR/CRD IV, stała się istotnym elementem systemu zarządzania bankiem i przedmiotem obowiązków informacyjnych, raz do roku bowiem banki przekazują KNF dane o liczbie osób, których

${ }^{17}$ Rozporządzenie Parlamentu Europejskiego i Rady nr 575/2013 z dnia 26 VI 2013 r. w sprawie wymogów ostrożnościowych dla instytucji kredytowych i firm inwestycyjnych, zmieniające rozporządzenie (UE) nr 648/2012 (Dz.Urz. UE L 176 z 27 VI 2013 r. s. 1).

${ }^{18}$ Dyrektywa nr 2013/36/UE Parlamentu Europejskiego i Rady z dnia 26 VI 2013 r. w sprawie warunków dopuszczenia instytucji kredytowych do działalności oraz nadzoru ostrożnościowego nad instytucjami kredytowymi i firmami inwestycyjnymi, zmieniająca dyrektywę 2002/87/WE (Dz.Urz. UE L 176 z 27 VI 2013 r., s. 338). 
działalność zawodowa ma istotny wpływ na profil ryzyka banku, jeśli ich łączne wynagrodzenie w poprzednim roku wyniosło co najmniej równowartość $1 \mathrm{mln}$ euro, wraz z informacjami dotyczącymi stanowisk zajmowanych przez te osoby oraz wartości głównych składników wynagrodzenia, przyznanych premii, nagród długookresowych oraz odprowadzonych składek emerytalnych. Z kolei KNF ma obowiązek przekazać te informacje i dane do Europejskiego Organu Nadzoru Bankowego (European Banking Authority).

Trzeba również zauważyć, że skoro, zgodnie z art. 9 ust. 2 pr. bank., system zarządzania stanowi zbiór zasad i mechanizmów odnoszących się do procesów decyzyjnych zachodzących w banku oraz do oceny prowadzonej działalności bankowej, to dotyka również zjawiska samoregulacji w banku, oczywiście wyznaczonej ramami prawnymi ustawy Prawo bankowe oraz rozporządzenia MF z 2017 r. i konkretyzowanej także rekomendacją H z 2017 r. W każdym banku musi zatem istnieć system zarządzania składający się co najmniej z systemu zarządzania ryzykiem i systemu kontroli wewnętrznej. Użycie sformułowania "co najmniej" oznacza możliwość poszerzenia przez banki systemu zarządzania w banku o inne jeszcze elementy, które w ocenie osób zarządzających bankiem mogą przyczynić się do usprawnienia systemu zarządzania. Obszar ten może właśnie stanowić pole do samoregulacji bankowej.

W ramach systemu kontroli wewnętrznej bank ma obowiązek wyodrębnić: (1) funkcję kontroli, mająca za zadanie zapewnienie przestrzegania mechanizmów kontrolnych dotyczących w szczególności zarządzania ryzykiem w banku, która obejmuje stanowiska, grupy ludzi lub jednostki organizacyjne odpowiedzialne za realizację zadań przypisanych tej funkcji; (2) komórkę do spraw zgodności, mającą za zadanie identyfikację, ocenę, kontrolę i monitorowanie ryzyka braku zgodności działalności banku z przepisami prawa, regulacjami wewnętrznymi i standardami rynkowymi oraz przedstawianie raportów w tym zakresie; (3) niezależną komórkę audytu wewnętrznego, mająca za zadanie badanie i ocenę, w sposób niezależny i obiektywny, adekwatności i skuteczności systemu zarządzania ryzykiem i systemu kontroli wewnętrznej, z wyłączeniem komórki audytu wewnętrznego. Brak wdrożenia w banku systemu kontroli wewnętrznej będzie oznaczał możliwość stosowania środków kontrolnych i nadzorczych przez KNF. 


\section{Kontrola zarządcza w sektorze publicznym a system kontroli wewnętrznej w sektorze bankowym - analiza porównawcza}

W teorii prawa finansowego, podobnie jak w innych działach prawa, przeprowadza się rozróżnienie na pojęcie "kontroli" i "nadzoru”, przy czym w każdej gałęzi prawa funkcjonuje wiele różnorodnych definicji i ujęć prawnych nadzoru oraz kontroli ${ }^{19}$. Wypracowane przez doktrynę prawa administracyjnego pojęcia "kontrola" $i$ "nadzór" ${ }^{\prime 20}$ zostały w dużym stopniu recypowane na grunt pozostałych gałęzi prawa ${ }^{21}, \mathrm{z}$ zastrzeżeniami specyfiki nadzorczo-kontrolnej dla każdej poszczególnej dyscypliny prawniczej22.

Na potrzeby niniejszego opracowania przyjmuje się jednak tradycyjnie, że stanowiąca przedmiot zainteresowania przedstawianego artykułu kontrola rozumiana jest: (1) jako ustalenie stanu faktycznego w badanym podmiocie czy jednostce podlegających procesowi kontroli; (2) jako ustalenie stanu prawnego wynikającego z założonego wzorca normatywnego (niejednokrotnie uwzględniającego nie tylko normy krajowe, ale również unijne czy normatywnie wyrażone wzorce gospodarności, rzetelności, celowości); (3) jako zestawienie, porównanie ustalonych stanów: faktycznego z normatywnym, dokonanie subsumcji oraz wyciągnięcie wniosków pokontrolnych ${ }^{23}$, które dalej mogą stać się materiałem istotnym dla procesów naprawczych, sanacyjnych czy

${ }^{19}$ Przykładowo, w prawie gospodarczym publicznym wyróżnia się m.in. nadzór prewencyjny, weryfikacyjny, represyjny i właścicielski; szerzej zob. C. Kosikowski, Publiczne prawo gospodarcze Polski i Unii Europejskiej, wyd. 4, Warszawa 2010, s. 303 i n. O nadzorze budowalnym zob. H. Kisilowska, D. Sypniewski, Prawo budowlane, Warszawa 2012, s. 124 i n.

${ }^{20}$ Zob. m.in. M. Szewczyk, Nadzór w materialnym prawie administracyjnym, Poznań 1996, passim; S. Jędrzejewski, Zakres pojęcia "nadzór" w doktrynie prawa administracyjnego (kolejna próba zbliżenia pogladów), w: Administracja publiczna u progu XXI w. Prace dedykowane prof. zw. dr. hab. Janowi Szreniawskiemu z okazji Jubileuszu 45-lecia pracy naukowej, pod red. Z. Niewiadomskiego, Przemyśl 2000, s. 274 i n.

${ }^{21}$ Posługiwanie się w prawie krajowym (polskim) elementami koncepcji nadzoru wypracowanymi w doktrynie prawa administracyjnego jest pozytywnie zweryfikowane w literaturze przedmiotu, zob. zwłaszcza L. Góral, Nadzór bankoww, Warszawa 1998, passim.

${ }^{22}$ Zauważono jednak zarazem znaczną elastyczność pojęcia "nadzór” oraz trudności w zakresie stworzenia pewnej stałej treści tego pojęcia dla wszelkich przypadków, zob. szeroko na ten temat L. Bar, Studia $z$ dziedziny prawa administracyjnego, Wrocław-Warszawa-Kraków-Gdańsk 1971, s. 142 i n.

${ }^{23}$ Zob. szerzej L. Kurowski, E. Ruśkowski, H. Sochacka-Krysiak, Kontrola finansowa w sektorze publicznym, Warszawa 2000, s. 16 i n. 
również procesów nadzorczych ${ }^{24}$. Nadzór w niniejszym opracowaniu rozumiany jest bowiem jako prawem przewidziana kompetencja do zastosowania środków władczych, korygujących, których celem jest doprowadzenie badanego stanu rzeczy do stanu zgodnego z założonym wzorcem normatywnym ${ }^{25}$.

W nawiązaniu do powyższych ustaleń z zakresu teorii nauk prawnych należy wskazać, że analizowane w opracowaniu pojęcia i instytucje kontroli wewnętrznej i zarządczej mieszczą się z trudem (kontrola wewnętrzna) lub w niewielkim zakresie (kontrola zarządcza) w powyżej przedstawionym ogólnym pojęciu kontroli jako procesu ustalania stanów faktycznych i prawnych z punktu widzenia urzeczywistnienia określonych celów, a następnie dokonywania czynności porównawczych, z prawem do formułowania wniosków i uwag pokontrolnych. We wskazane w teorii nauk prawnych ramy prawne pojęcia "kontrola”, tam gdzie jest to możliwe, "wkomponowane" zostaną elementy treściowe dwóch analizowanych instytucji: „kontroli wewnętrznej” i "kontroli zarządczej".

Jak wiadomo, instytucja kontroli zarządczej pojawiła się w prawie finansów publicznych dopiero w obecnej ustawie o finansach publicznych, w miejsce wcześniejszej kontroli finansowej przewidzianej art. 47 ustawy o finansach publicznych z $2005 \mathrm{r} .{ }^{26} \mathrm{~W}$ obecnej ustawie o finansach publicznych w rozdziale 6 zatytułowanym "Kontrola zarządcza oraz koordynacja kontroli zarządczej w jednostkach sektora finansów publicznych" wprowadzono tę instytucję rozumianą w art. 68 u.f.p.

${ }^{24}$ Zasadniczo pojęcie "kontrola” u większości autorów na przestrzeni lat nie podlegało co do zasady większym modyfikacjom, gdyż w jego treści zawierało się zawsze badanie, ustalanie, sprawdzanie, wykrywanie stanu faktycznego podmiotu kontrolowanego, porównanie ustaleń z normami prawnymi i wyciągnięcie wniosków pokontrolnych oraz sformułowanie zaleceń, zob. m.in. W. Dawidowicz, Zagadnienia ustroju administracji w Polsce, Warszawa 1970, s. 34; zob. też Z. Leoński, Zarys prawa administracyjnego, Warszawa 2006, s. 197; A. Filipowicz, Pojęcie i funkcja nadzoru w administracji państwowej, Wrocław-Warszawa-Kraków-Gdańsk 1984, s. 71 i n.

${ }^{25} \mathrm{O}$ nadzorze na rynku finansowym zob. R. Kaszubski, Funkcjonalne źródła prawa bankowego publicznego, Warszawa 2006, s. 54; A. Dobaczewska, Nadzór bankowy, w: Leksykon prawa finansowego. 100 podstawowych pojęć, pod red. A. Drwiłło, D. Maśniak, Warszawa 2009, s. 214; D. Wojtczak, Nadzorowanie instytucji finansowych, w: Prawo finansowe, pod red. E. Fojcik-Mastalskiej, R. Mastalskiego, Warszawa 2011, s. 488, 489; M. Fedorowicz, Nadzór na rynku finansowym Unii Europejskiej, Warszawa 2013, passim.

${ }^{26}$ Szerzej na ten temat zob. B. Kołaczkowski, M. Ratajczak, System wewnętrznej kontroli finansowej w jednostkach samorząu terytorialnego w świetle uregulowań ustawy z 27.08.2009 r. o finansach publicznych, "Finanse Komunalne” 2010, nr 4, s. 52-65. 
jako ogół działań podejmowanych dla zapewnienia realizacji celów i zadań jednostek sektora finansów publicznych w sposób zgodny z prawem, efektywny, oszczędny i terminowy ${ }^{27}$ oraz będących procesem realizowanym w sposób ciągły ${ }^{28}$. I już samo tylko opisowe tłumaczenie terminu "kontrola zarządcza" ${ }^{29} \mathrm{w}$ ustawie o u.f.p. pokazuje, że jest to termin szerszy niż dotychczasowe pojęcie kontroli finansowej w finansach publicznych czy pojęcie "kontroli” tradycyjnie stosowane w teorii nauk prawnych ${ }^{30}$. Można wskazać, że kontrola zarządcza składa się na pewien wewnętrzny system kontroli, obowiązujący w jednostkach sektora finansów publicznych i pretendujący do miana nowoczesnego modelu zarządzania finansami publicznymi z punktu widzenia spełnienia celów tej kontroli normatywnie wyrażonych w art. 68 ustawy u.f.p., dla których obok kryterium zgodności z prawem wyszczególniono także m.in. efektywność, oszczędność czy terminowość. Wskazuje się również, że kontrola zarządcza reprezentuje nową kulturę zarządzania publicznego, której elementami są: wprowadzenie zarządzania menadżerskiego w sektorze publicznym, precyzyjne określenie standardów i mierników działalności, położenie akcentu na kontrolę uzyskiwanych wyników i właściwe wykorzystywanie metod i technik zarządzania $\mathrm{z}$ sektora prywatnego ${ }^{31}$ oraz dbałość o zapewnienie w praktyce integracji systemów zarządzania jakością z zasadami kontroli zarządczej ${ }^{32}$.

${ }^{27}$ Szerzej na temat kontroli zarządczej zob. D. Fleszer, Audyt wewnętrzny i jego rola w zarządzaniu jednostką sektora finansów publicznych, "Finanse Komunalne” 2014, nr 5, s. 57-68; A. Wójtowicz-Dawid, Kontrola zarządcza w kontekście zmiany prawa, osiagania określonego celu oraz efektywności zmian, "Przegląd Prawa Publicznego" 2014, nr 7-8, s. 162-169.

${ }_{28}$ M. Dębowska-Sołtyk, Kontrola zarządcza w jednostkach samorzadu terytorialnego - cel i zadania systemu, "Finanse Komunalne” 2011, nr 7-8, s. 85-97.

${ }^{29}$ Abstrahując w tym miejscu od przybliżania argumentów dotyczących możliwości wywodzenia kontroli zarządczej od kontroli wewnętrznej czy kontroli finansowej, wypada opowiedzieć się jednak za podobieństwem kontroli zarządczej właśnie do kontroli wewnętrznej. Szerzej zob. E.W. Babuśka, Koncepcja kontroli zarządczej w sektorze finansów publicznych, "Zeszyty Naukowe Uniwersytetu Szczecińskiego. Finanse. Rynki Finansowe. Ubezpieczenia" 2011, nr 42, s. 19, oraz M. Kaczurak-Kozak, Kontrola zarzaddzza jako nowy wymiar kontroli w sektorze finansów publicznych, "Zeszyty Naukowe Uniwersytetu Szczecińskiego. Finanse. Rynki Finansowe. Ubezpieczenia" 2011, nr 42, s. 69. Co do pojęcia kontroli zarządczej zob. C. Kosikowski, Komentarz do art. 68 ustawy o finansach publicznych, wyd. 2, LexisNexis/el. 2011.

${ }^{30}$ D. Adamek-Hyska, Kontrola zarzadcza w jednostkach sfery publicznej, Komentarz praktyczny LEX/el. ABC.

${ }^{31}$ Tak I. Rosiek, op. cit.

${ }^{32}$ M. Bugdol, Możliwości integracji kontroli zarządczej z systemami zarządzania jakościa wedtug normy ISO 9001:2008, „Samorząd Terytorialny” 2012, nr 9, s. 65-72. 
Z punktu widzenia postawionych celów badawczych w opracowaniu istotna jest rekonstrukcja pojęcia "kontrola" oraz wskazanie jej celów, kryteriów i funkcji, dla następczego wykazania jej podobieństw lub różnic z regulacyjnie odpowiadającym jej na gruncie prawa bankowego systemem kontroli wewnętrznej z art. 9-9f pr. bank. W art. 68 ust. 2 u.f.p. uszczegółowiono cele kontroli zarządczej, wprowadzając do katalogu otwartego zwłaszcza zapewnienie: zgodności działalności z przepisami prawa oraz procedurami wewnętrznymi; skuteczności i efektywności działania ${ }^{33}$; wiarygodności sprawozdań; ochrony zasobów; przestrzegania i promowania zasad etycznego postępowania; efektywności i skuteczności przepływu informacji; i w końcu zarządzania ryzykiem $^{34}$. Natomiast obowiązek zapewnienia funkcjonowania tego wewnętrznego systemu kontroli nałożono na ministrów kierujących określonym działem administracji rządowej, na wójtów, burmistrzów czy prezydentów miast, a także przewodniczącego zarządu jednostki samorządu terytorialnego oraz kierownika jednostki.

Warto również dodać, że w ustawie o odpowiedzialności za naruszenie dyscypliny finansów publicznych z 2004 r. zaniechanie obowiązku prowadzenia tej kontroli potraktowano jako czyn stanowiący naruszenie dyscypliny finansów publicznych ${ }^{35}$. W art. 18c ustawy o odpowiedzialności za naruszenie dyscypliny finansów publicznych wskazano, po pierwsze, że naruszenie obowiązków w zakresie kontroli zarządczej może dotyczyć tylko kierownika jednostki sektora finansów publicznych, i po drugie, że naruszenie obowiązków w zakresie kontroli zarządczej będzie stanowiło czyn podlegający tej ustawie, jeśli wykazany zostanie wpływ tego działania lub zaniechania ${ }^{36} \mathrm{~m}$.in. na uszczuplenie wpływów należnych danej jednostce czy dokonanie wydatków powodujących

${ }^{33}$ Zob. szerzej M. Jasztal, Kontrola skuteczności i efektywności działania, Komentarz praktyczny LEX/el. ABC.

${ }^{34} \mathrm{Na}$ ten temat zob. szerzej T. Jarząbek, L. Ochmańska, Cele i zarządzanie ryzykiem w kontroli zarządczej, Komentarz praktyczny LEX/el. ABC.

${ }^{35}$ Ustawa z dnia 17 XII 2004 r. o odpowiedzialności za naruszenie dyscypliny finansów publicznych (tekst jedn. Dz.U. 2017 Nr 1311 ze zm.).

${ }^{36}$ Słusznie podkreśla się, że w konkretnej sytuacji wykazanie tego wpływu, stanowiącego element konstrukcji normatywnej odpowiedzialności kierownika jednostki za niedopełnienie obowiązków wynikających z kontroli zarządczej, jest trudne, a kształt normatywny tych przepisów niedoskonały i zmuszający do postawienia pytań o zasadę określoności tych przepisów prawnych; zob. interesujące uwagi W. Witalec, Kontrola zarządcza w jednostkach sektora finansów publicznych a naruszenie dyscypliny finansów publicznych, „Finanse Komunalne” 2012, nr 4, s. 52-63. 
przekroczenie kwot ujętych w planie finansowym danej jednostki ${ }^{37}$. Należy wskazać, że stało się to wyrazem założenia, iż potrzebne są nowoczesne metody zarządzania organizacją publiczna, czy też organizacją zarządzającą środkami publicznymi, które niwelować będą ryzyko powstające $\mathrm{w}$ razie niestosowania się do norm prawnych i kryteriów kontroli $^{38}$.

Z kolei cele kontroli wewnętrznej, tworzącej cały system kontroli wewnętrznej, zgodnie $\mathrm{z}$ art. 9c ust. 1 pr. bank., obejmują zapewnienie: (1) skuteczności i efektywności działania banku; (2) wiarygodności sprawozdawczości finansowej; (3) przestrzegania zasad zarządzania ryzykiem w banku; (4) zgodności działania banku z przepisami prawa, regulacjami wewnętrznymi i standardami rynkowymi. Wdrożenie i przestrzeganie systemu kontroli wewnętrznej w bankach zgodnie z $\S 32$ rozporządzenia Ministra Finansów z 2017 r. należy do obowiązków zarządu banku. Do jego kompetencji należy projektowanie, wprowadzenie oraz zapewnianie we wszystkich jednostkach organizacyjnych, komórkach organizacyjnych i stanowiskach organizacyjnych banku funkcjonowania adekwatnego i skutecznego systemu kontroli wewnętrznej, który obejmuje funkcję kontroli, komórkę do spraw zgodności i komórkę audytu wewnętrznego oraz zapewnia niezależność.

Z kolei w realizacji kompetencji z zakresu kontroli zarządczej, na podstawie art. 69 ust. 3 u.f.p., Minister Finansów określił szczegółowe wytyczne w sprawie standardów kontroli zarządczej dla sektora finansów publicznych ${ }^{39}$. Standardy te stanowią minimalny wzorzec (gdyż określają podstawowe wymagania) przewidziany do stosowania w sektorze finansów publicznych. Nie tworzą one jednak zamkniętego katalogu, ponieważ system kontroli zarządczej powinien być elastyczny i dostosowany do specyficznych potrzeb jednostki, działu administracji rządowej lub jednostki samorządu terytorialnego. Celem tych standardów jest promowanie wdrażania w sektorze finansów publicznych spójnego i jednolitego modelu kontroli zarządczej, zgodnego $\mathrm{z}$ międzynarodowymi standardami w tym zakresie, z uwzględnieniem

${ }^{37}$ Warto podkreślić, że art. 18c został dodany przez art. 1 pkt 14 Ustawy z dnia 19 sierpnia 2011 r. (Dz.U. Nr 240, poz. 1429) zmieniającej ustawę o odpowiedzialności za naruszenie dyscypliny finansów publicznych z dniem 11 II $2012 \mathrm{r}$.

${ }^{38} \mathrm{Na}$ ten temat zob. szerzej M. Dębowska-Sołtyk, P. Sołtyk, Kary za naruszenie dyscypliny finansów publicznych jako skutek dysfunkcji gospodarowania środkami publicznymi, „Finanse Komunalne" 2015, nr 5, s. 41-53.

${ }^{39}$ Komunikat nr 23 Ministra Finansów z 16 XII 2009 r. w sprawie standardów kontroli zarządczej dla sektora finansów publicznych (Dz.Urz. MF 2009 Nr 84, poz. 15). 
specyficznych zadań jednostki, która ją wdraża, i warunków, w których jednostka działa. Warto podkreślić, że również audytor wewnętrzny prowadzi obiektywną i niezależną ocenę kontroli zarządczej.

Zgodnie ze standardami za najistotniejszy element kontroli zarządczej w dziale administracji rządowej i jednostce samorządu terytorialnego należy uznać system wyznaczania celów i zadań dla jednostek w danym dziale administracji rządowej lub samorządowych jednostek organizacyjnych, a także system monitorowania realizacji wyznaczonych celów i zadań.

Jak wiadomo, kształt kontroli zarządczej i jej wykorzystanie w sektorze publicznym wiąże się z uwzględnieniem międzynarodowych standardów $\mathrm{COSO}^{40}$, INTOSAI ${ }^{41}$ oraz SEC ${ }^{42}$. Wykorzystanie standardów w sektorze publicznym ma przybliżać ten sektor do innowacyjnych metod i technik zarządzania oraz sprawić, aby podejmowane działania w większym stopniu skorelowane były z dorocznie weryfikowanymi i ustalanymi celami oraz realizacją zadań. Tym samym właśnie w obszarze kontroli zarządczej najpełniej uwidacznia się realizacja działań zgodnie z kryteriami skuteczności i efektywności.

Analizując standardy, trzeba jednak zauważyć duże podobieństwo standardów do regulacji systemu kontroli wewnętrznej w prawie bankowym. Zreszta, jak zaznaczono powyżej, standardy COSO wykorzystywane $w$ regulacji standardów kontroli zarządczej dotyczą kontroli wewnętrznej i zarządzania ryzykiem w przedsiębiorstwie. Kategoria pojęciowa zarządzania ryzykiem - do 2009 r. - była bardziej związana z sektorem bankowym, gdzie identyfikacja i ocena ryzyka finansowego w tej działalności jest fundamentem bezpiecznego funkcjonowania rynku finansowego. Odnosząc tę paralelę do sektora publicznego, można stwierdzić, że wprowadzenie kontroli zarządczej ma sprzyjać nie tylko efektywnemu zarządzaniu ryzykiem, ale również uwzględniać kryteria oszczędności i skuteczności, tak aby w systemowy sposób identyfikować

\footnotetext{
40 "Kontrola wewnętrzna - zintegrowana koncepcja ramowa” oraz "Zarządzanie ryzykiem w przedsiębiorstwie" - raporty opracowane przez Komitet Organizacji Sponsorujących Komisję Treadway (Committee of Sponsoring Organizations of the Treadway Commission - COSO).

${ }^{41}$ "Wytyczne w sprawie standardów kontroli wewnętrznej w sektorze publicznym" przyjęte w 2004 r. przez Międzynarodową Organizację Najwyższych Organów Kontroli/ Audytu (International Organization of Supreme Audit Institutions - INTOSAI).

${ }_{42}$ "Zmienione Standardy Kontroli Wewnętrznej służące skutecznemu zarządzaniu" Komisji Europejskiej przyjęte w 2007 r. (The Revised Internal Control Standard for Effective Management SEC (2007) 1341, appendix 1).
} 
ryzyko, dokonywać jego analizy oraz określać sposób najbardziej adekwatnej reakcji na nie.

Warto zwrócić uwagę, że zgodnie z art. 9 pr. bank. na banki nałożono obowiązek wprowadzenia wewnętrznego systemu zarządzania, stanowiącego zbiór zasad i mechanizmów odnoszących się do procesów decyzyjnych zachodzących w banku oraz do oceny prowadzonej działalności bankowej i obejmującego co najmniej system zarządzania ryzykiem oraz system kontroli wewnętrznej. Regulacyjnie podobnie, kontrola zarządcza obejmuje głównie gospodarkę finansową jednostek sektora finansów publicznych i stanowi ogół działań podejmowanych dla zapewnienia realizacji celów i zadań w sposób zgodny z prawem, efektywny, oszczędny i terminowy. $W$ jednym i drugim przypadku kontrola dotyczy wewnętrznego sposobu zarządzania ryzykiem oraz zapewniania efektywnej realizacji odnośnych celów i zadań. W jednym i drugim przypadku cele kontroli unormowane są bardzo podobnie. Regulacyjnie podobieństwo tych instytucji, przy oczywistym zastrzeżeniu różnic materialnoprawnych i w zakresie obszaru prawa, w którym są stosowane, polega na tym, że poprzez wyznaczenie celów, monitoring i weryfikację podejmowanego ryzyka na bieżąco przeprowadza się czynności samosanujące działalność podmiotów i realizowane działania.

Oprócz zarządzania ryzykiem do celów kontroli zarządczej zalicza się również przestrzeganie i promowanie zasad etycznego postępowania. Rozumiane jest to w standardach jako konieczność zapewnienia i kształtowania właściwego środowiska wewnętrznego, a więc właśnie takiego, które w swej działalności i realizowanych zadaniach wspierać będzie przestrzeganie wartości etycznych. Osoby zarządzające i pracownicy powinni być świadomi wartości etycznych przyjętych w jednostce i przestrzegać ich przy wykonywaniu powierzonych zadań. Słusznie konkretyzowane są te standardy jako dbałość o to, aby osoby zarządzające i pracownicy posiadali wiedzę, umiejętności i doświadczenie pozwalające skutecznie i efektywnie wypełniać powierzone zadania. Wskazany standard przypomina niedawno wprowadzoną do prawa bankowego, wspomnianą już powyżej, instytucję whistleblowing, czyli procedurę anonimowego zgłaszania wskazanemu członkowi zarządu, a w szczególnych przypadkach radzie nadzorczej banku naruszeń prawa oraz obowiązujących w banku procedur i standardów etycznych. Warto również podkreślić, że standardy prawidłowego i rzetelnego systemu zarządzania oraz systemu kontroli wewnętrznej są pochodną przyjęcia w prawie bankowym, iż bank jest instytucją zaufania publicznego, co 
przejawia się również w przestrzeganiu i promowaniu standardów etycznych w działalności bankowej. Natomiast zgodnie z $\S 45$ rozporządzenia MF z 2017 r. bank ma obowiązek opracowywać i wdrażać procedury anonimowego zgłaszania przez pracowników naruszeń prawa oraz obowiązujących w banku procedur i standardów etycznych.

Kolejnym obszarem wykazującym znaczne analogie regulacyjne w zakresie zapewniania systemów zarządzania ryzykiem i kontroli wewnętrznej w sektorze publicznym i prywatnym jest identyfikacja, zarządzanie i monitorowanie ryzyka w działalności instytucji sektora publicznego i bankowego. Zgodnie ze standardami kontroli zarządczej zarządzanie ryzykiem ma na celu zwiększenie prawdopodobieństwa osiągnięcia celów i realizacji zadań. Jak już wskazano, zarządzanie ryzykiem jest najbardziej "rynkowym” elementem obecnym w działalności sektora publicznego. Ważne, że w standardach kontroli zarządczej wskazano, iż co najmniej raz w roku należy dokonać identyfikacji ryzyka (a w razie istotnej zmiany warunków - ponownej identyfikacji) w odniesieniu do celów i zadań, a w przypadku działu administracji rządowej lub jednostki samorządu terytorialnego należy uwzględnić, iż cele i zadania są realizowane także przez jednostki podległe lub nadzorowane.

Z kolei zarządzanie ryzykiem finansowym w działalności instytucji finansowych jest fundamentalnym elementem nie tylko kontroli wewnętrznej w sektorze bankowym, ale również zasadniczym celem podstawowej działalności bankowej, który polega właśnie na efektywnym i bezpiecznym identyfikowaniu, wyważaniu i zarządzaniu ryzykiem w działalności bankowej, co stanowi w istocie źródło zysków instytucji finansowych. Zgodnie z art. 9b. ust. 1 pr. bank. zadaniami systemu zarządzania ryzykiem są: identyfikacja, pomiar lub szacowanie, kontrola oraz monitorowanie ryzyka występującego w działalności banku służące zapewnieniu prawidłowości procesu wyznaczania i realizacji szczegółowych celów prowadzonej przez bank działalności. W ramach systemu zarządzania ryzykiem bank: (1) stosuje sformalizowane zasady służące określaniu wielkości podejmowanego ryzyka i zasady zarządzania ryzykiem; (2) stosuje sformalizowane procedury mające na celu identyfikację, pomiar lub szacowanie oraz monitorowanie ryzyka występującego w działalności banku, uwzględniające również przewidywany poziom ryzyka w przyszłości; (3) stosuje sformalizowane limity ograniczające ryzyko i zasady postępowania w przypadku przekroczenia limitów; (4) stosuje przyjęty system sprawozdawczości zarządczej umożliwiający 
monitorowanie poziomu ryzyka; (5) posiada strukturę organizacyjną dostosowaną do wielkości i profilu ponoszonego przez bank ryzyka.

Organizacja systemu zarządzania ryzykiem i systemu kontroli wewnętrznej w banku, zgodnie z rozporządzeniem MF z 2017 r., przebiega na trzech poziomach, które są niezależne, co ma gwarantować lepsze wykonanie zadań. Na pierwszy poziom składa się zarządzanie ryzykiem w działalności operacyjnej banku, natomiast na drugi poziom składa się co najmniej: zarządzanie ryzykiem przez pracowników na specjalnie powoływanych do tego stanowiskach lub w komórkach organizacyjnych oraz działalność komórki do spraw zgodności. Z kolei trzeci poziom wyznacza działalność komórki audytu wewnętrznego. Do ważnych zagadnień związanych z systemem zarządzania ryzykiem zaliczyć należy postanowienia konkretyzujące zarządzanie tym ryzykiem a obejmujące, zgodnie z $\$ 7$ tego rozporządzenia: identyfikację, pomiar lub szacowanie, kontrolę, monitorowanie ryzyka oraz raportowanie o ryzyku. W banku funkcjonuje system sprawozdawczości zarządczej, wspomagający proces decyzyjny w zakresie zarządzania ryzykiem w banku, na który składa się w szczególności raportowanie o ryzyku. Można uznać, że właśnie sprawozdawczość zarządcza jest kluczem do prawidłowego zarządzania ryzykiem.

Do cennych postanowień usprawniających zarządzanie ryzykiem należą również postanowienia nakładające na bank, na podstawie $\S 21$ rozporządzenia MF z 2017 r., m.in. przed wprowadzeniem nowego produktu, obowiązek przeprowadzenia procesu przygotowawczego, obejmującego zwłaszcza analizę zgodności produktu ze strategią zarządzania bankiem i strategią zarządzania ryzykiem; identyfikację istotnych rodzajów ryzyka związanych z produktem $\mathrm{w}$ ramach systemu zarządzania ryzykiem; uwzględnienie rodzaju produktu w stosowanych metodach identyfikacji, pomiaru lub szacowania ryzyka; ustalenie limitów, zasad ewidencji księgowej i raportowania; zatwierdzenie wprowadzenia produktu przez zarząd banku lub odpowiednie komitety powołane przez zarząd banku ${ }^{43}$.

Z kolei na podstawie art. 69 ust. 4 u.f.p. Minister Finansów określił szczegółowe wytyczne w zakresie planowania działalności i zarządzania ryzykiem dla jednostek sektora finansów publicznych ${ }^{44}$. Szczególnie element zarządzania ryzykiem w sektorze finansów publicznych

${ }^{43}$ M. Fedorowicz, System zarządzania ryzykiem i system kontroli wewnętrznej w bankach, Komentarz praktyczny Lex dla Banków nr 320628, s. 1-10.

${ }^{44}$ Dz.Urz. MF 2012, poz. 56. 
stanowi o zaadaptowaniu kategorii znanej rynkowi finansowemu do sfery finansów publicznych. Słusznie uznaje się, że terminowa realizacja określonych celów i zadań publicznych, zgodnie z przepisami prawa, w sposób oszczędny i efektywny jest obarczona ryzykiem i stąd tworzenie polityk i procedur koordynowania działań jest nieodzowne dla identyfikacji czy analizy źródeł ryzyka, a następnie zarządzania tym ryzykiem. Zgodnie z analizowanymi wytycznymi Ministra Finansów dwupoziomowy system zarządzania ryzykiem w kontroli zarządczej (I poziom - jednostka sektora finansów publicznych, II poziom - dział administracji rządowej/jednostka samorządu terytorialnego) polega m.in. na: stosowaniu jednolitej metodologii zarządzania ryzykiem, przeprowadzaniu samooceny kontroli zarządczej ${ }^{45}$, składaniu oświadczenia o stanie kontroli zarządczej przez podmioty odpowiedzialne w ramach II poziomu. Natomiast na podstawie art. 71 u.f.p. do zadań Ministra Finansów należy koordynacja kontroli zarządczej w jednostkach sektora finansów publicznych, która przejawia się w: upowszechnianiu standardów kontroli zarządczej; wydawaniu wytycznych; współpracy z krajowymi i zagranicznymi organizacjami oraz współpracy z komitetami audytu. Urzeczywistnienie celu zarządzania ryzykiem jako celu kontroli zarządczej również jest uzależnione ex ante od otrzymywania informacji zarządczej.

Minister Finansów określił też w formie komunikatu szczegółowe wytyczne w zakresie kontroli zarządczej dla jednostek sektora finansów publicznych dotyczące samooceny kontroli zarządczej tych jednostek jako instrumentu monitorowania i oceny funkcjonowania kontroli zarządczej ${ }^{46}$.

\section{Podsumowanie}

Analizy przeprowadzone w opracowaniu wykazują, że instytucje obecne w sektorze rynkowym mogą być wykorzystywane do osiągania celów istotnych dla finansów publicznych. Tworzyć to może i powinno nowy

${ }^{45}$ Samoocena kontroli zarządczej ma szczególne znaczenie w przypadku tych jednostek, które nie dysponują innymi narzędziami oceny kontroli zarządczej, np. audytem wewnętrznym. Zob. Komunikat nr 3 Ministra Finansów z 16 II 2011 r. w sprawie szczegółowych wytycznych w zakresie samooceny kontroli zarządczej dla jednostek sektora finansów publicznych (Dz.Urz. MF 2011 Nr 2, poz. 11).

${ }^{46}$ Komunikat nr 3 Ministra Finansów z dnia 16 II 2011 r. w sprawie szczegółowych wytycznych w zakresie samooceny kontroli zarządczej dla jednostek sektora finansów publicznych (Dz.Urz. MF 2011 Nr 2, poz. 11). 
trend regulacyjny - szerokiego uwzględniania w regulacjach z zakresu finansów publicznych instytucji (w sensie przedmiotowym) właściwych prawu bankowemu czy prawu rynku finansowego.

Takie regulacyjne wykorzystanie instytucji prawnych z obszaru prawa rynku finansowego $\mathrm{w}$ finansach publicznych, zwłaszcza w elemencie kontroli i zarządzania ryzykiem, wydaje się szczególnie potrzebne i może stanowić dobry regulacyjny wyznacznik na przyszłość. Spełnia bowiem kilka celów: (1) wyraża możliwość w określonym zakresie „rynkowego" spojrzenia na prawo finansów publicznych; (2) jest wyrazem możliwości samoregulacyjnych sektora finansów publicznych w zakresie tej kontroli; (3) wspiera funkcjonalnie i wewnętrznie rozumianą zasadę ponoszenia odpowiedzialności za popełnione błędy w zakresie kontroli zarządczej.

System kontroli wewnętrznej w prawie bankowym i kontroli zarządczej w prawie finansów publicznych są wewnątrzsystemowymi elementami wspierania zasady bezpieczeństwa obrotu prawnego i bezpieczeństwa prawnego. Wymienione instytucje kontrolne są do siebie regulacyjnie podobne zarówno w zakresie celów, pełnionych funkcji, jak i metody regulacyjnej, z tym że w sektorze publicznym dookreślenie kontroli zarządczej odbywa się za pomocą wzorców i standardów postępowania wyznaczonych w komunikacie Ministra Finansów ${ }^{47}$. Z tego punktu widzenia w prawie bankowym uregulowanie dotyczące systemu kontroli wewnętrznej jest pełniejsze i bazuje na ustawie oraz rozporządzeniu, a zatem na znormatywizowanych wzorcach, które mogą być także określane w wytycznych i zalecaniach Europejskich Organów Nadzoru Finansowego (ESA, European Supervisory Authorities), zgodnie $\mathrm{z}$ art. 133 ust. 1a ustawy pr. bank. podlegających uwzględnieniu przez KNF, np. w drodze włączenia do rekomendacji KNF czy po prostu do aktów prawa UE i krajowego w formie odpowiednio: dyrektyw i rozporządzeń (również delegowanych i wykonawczych) oraz ustaw.

Można zauważyć, że w prawie bankowym występuje większa precyzja regulacyjna niż $\mathrm{w}$ ustawie o finansach publicznych $\mathrm{i}$, jak już słusznie podkreślono w piśmiennictwie, nie powinno być tak, że w przepisach o charakterze odpowiedzialnościowym pojawiają się zwroty uzależniające pociągnięcie do odpowiedzialności za naruszenie dyscypliny finansów publicznych, o ile miały wpływ na szeroko pojęte uszczuplenia środków publicznych, gdyż występuje poważny problem z interpretacją

\footnotetext{
${ }^{47}$ Zob. zwłaszcza W. Witalec, op. cit., s. 52-63.
} 
sformułowania „wpływ"48. W tym kontekście system kontroli wewnętrznej w prawie bankowym wydaje się, już choćby tylko na poziomie regulacyjnym, zdecydowanie lepiej unormowany.

Trzeba jednak także wspomnieć, z punktu widzenia podstaw prawnych analizowanych instytucji, że w elemencie kontroli zarówno $\mathrm{w}$ prawie bankowym, jak i w prawie finansów publicznych pojawia się możliwość rozwinięcia działalności samoregulacyjnej, odpowiednio, banków czy jednostek sektora finansów publicznych, która oczywiście wyznaczona jest ramami prawnymi nie tylko regulacji krajowych, ale też unijnych (np. w zakresie polityki wynagrodzeń w prawie bankowym czy w odniesieniu do samokontroli zarządczej polegającej na sporządzaniu raportów samooceny). Rzecz jasna, należy ponadto zwrócić uwagę na niepokojące zjawisko rozrostu i wzmocnionego obiegu dokumentacji kontrolnej i sprawozdawczej. Z tego punktu widzenia wydaje się, że ponownie lepiej uregulowano system kontroli wewnętrznej w prawie bankowym, wyznaczając mu ramy w ustawie i rozporządzeniu Ministra Finansów, pozostawiając zarazem w pewnym zakresie swobodę decyzyjną organom zarządzającym bankiem. W odniesieniu do kontroli zarządczej przykładowo określone w standardach (komunikatach Ministra Finansów) raporty samooceny czy standardy prowadzenia kontroli zarządczej nie muszą być jednolicie stosowane bądź rozumiane przez jednostki sektora finansów publicznych, skoro standardy te nie zostały przyjęte w formie rozporządzenia. Sytuacja ta może mieć jednak pozytywne strony, stwarza bowiem możliwość wewnętrznego wypracowania i przyjęcia takiego sposobu prowadzenia kontroli zarządczej, który będzie ukierunkowany na specyfikę działalności danej jednostki sektora finansów publicznych.

W kontroli zarządczej obowiązki nałożono na kierownika jednostki sektora finansów publicznych i ministrów resortowych oraz wójta, burmistrza czy prezydenta miasta i przewodniczącego zarządu jednostki samorządu terytorialnego na podstawie art. 69 u.f.p., a nieprzestrzeganie postanowień $\mathrm{z}$ zakresu kontroli zarządczej, zgodnie $\mathrm{z}$ art. 18c ustawy o odpowiedzialności za naruszenie dyscypliny finansów publicznych, stanowi jej naruszenie. Z kolei zapewnienie systemu kontroli wewnętrznej w bankach jest obowiązkiem zarządu banku, zgodnie bowiem z art. 9a pr. bank. to zarząd banku projektuje, wprowadza oraz zapewnia działanie systemu zarządzania, a rada nadzorcza sprawuje

\footnotetext{
${ }^{48}$ Ibidem.
} 
nadzór wewnętrzny nad wprowadzeniem systemu zarządzania oraz ocenia adekwatność i skuteczność tego systemu. Natomiast nadzór nad przestrzeganiem przez bank postanowień art. 9-9f ustawy pr. bank. pełni KNF.

Po przeprowadzeniu porównania systemu kontroli wewnętrznej i kontroli zarządczej można zauważyć, że pojęcie oraz cele systemu kontroli wewnętrznej i kontroli zarządczej są analogiczne, z oczywistym zastrzeżeniem różnic obszaru prawa bankowego i prawa finansów publicznych. Występujące w prawie finansów publicznych znaczące odwzorowanie systemu kontroli wewnętrznej w kontroli zarządczej formułowane może być również na podstawie porównania kryteriów realizowanych kontroli, w obydwu przypadkach uwzględniających m.in. skuteczność, efektywność, właściwe zarządzanie ryzykiem czy monitorowanie tego ryzyka, wiarygodność sprawozdawczości kontrolnej (finansowej) oraz zgodność działania banku (czy jednostki sektora finansów publicznych) z przepisami prawa, regulacjami wewnętrznymi bądź standardami rynkowymi właśnie (art. 9c ust. 1 pr. bank. i art. 68 ust. 2 u.f.p.).

Dokonane analizy porównawcze pozwoliły na sformułowanie twierdzenia o istnieniu analogicznych funkcji pełnionych przez system kontroli wewnętrznej w prawie bankowym i kontroli zarządczej w prawie finansów publicznych. Należą do nich: (1) funkcja kontrolna, (2) funkcja monitorowania ryzyka oraz (3) funkcja, którą można by nazwać funkcją wzmacniającą zdolności samoregulacyjne, odpowiednio, banków czy jednostek sektora finansów publicznych. Wydaje się jednak, że w różny sposób rozłożone są akcenty normatywne poszczególnych analizowanych funkcji w zakresie omawianych uregulowań. W odniesieniu do pierwszej funkcji można wskazać, że analizy treści pojęć "system kontroli wewnętrznej” oraz „kontrola zarządcza” skupiają się na ustaleniu wzorców kontrolnych - z zastrzeżeniem różnorodności obszarów badanej materii - wywodzących się zarówno z prawa UE, jak i prawa polskiego, a dotyczących ulokowania mechanizmów kontrolnych wewnątrz banków i jednostek sektora finansów publicznych, których istnienie i prawidłowe funkcjonowanie zagwarantowane jest możliwością użycia środków nadzorczych przez KNF (system kontroli wewnętrznej) lub zainicjowania procedury za naruszenie dyscypliny finansów publicznych (kontrola zarządcza). W odniesieniu z kolei do funkcji monitorowania ryzyka uznać należy, że zarówno w odniesieniu do systemu kontroli wewnętrznej, ulokowanej w szerzej pojętym 
mechanizmie zarządzania bankiem, jak i w odniesieniu do kontroli zarządczej element identyfikacji ryzyka i jego ewaluacji stanowi ważny element procesu kontrolnego, będąc w sektorze bankowym fundamentem prowadzonej działalności finansowej, a w finansach publicznych nowszym instrumentem, słusznie pomyślanym jako nowoczesny, "rynkowy" instrument zarządzania działalnością jednostek sektora finansów publicznych. Trzecia z wyróżnionych funkcji, wzmacniająca zdolności samoregulacyjne, odpowiednio, banków albo jednostek sektora finansów publicznych, związana jest z wewnętrznym charakterem instytucji kontrolnych. Zarówno w regulacji systemu kontroli wewnętrznej w prawie bankowym, jak i w kontroli zarządczej w prawie finansów publicznych istnieje możliwość ustalania przez banki czy jednostki sektora finansów publicznych wzorców postępowania bardziej rygorystycznych, jak i dostosowanych do specyfiki realizowanej działalności, oczywiście w zakreślonych ramach prawnych. Ten obszar występujący pomiędzy wiążącymi regulacjami minimalnymi a możliwością dookreślenia postępowania za pomocą strategii czy różnych rodzajów polityki bankowej z jednej strony, a z drugiej dokumentów ewaluujących kontrolę zarządczą można zaliczyć do obszaru dostępnej samoregulacji dla podmiotów objętych tymi uregulowaniami. Wydaje się jednak, że wskazana samoregulacja jest zapewniona w większym stopniu w prawie bankowym, system kontroli wewnętrznej nastawiony jest bowiem na wewnętrzne przyporządkowanie organom decyzyjnym banku określonych funkcji kontrolno-nadzorczych, a ponadto na wypracowanie mechanizmów samonaprawczych (whistleblowing). System kontroli wewnętrznej $\mathrm{w}$ bankach stanowi potrzebną ex ante kontrolę działań banku, łącznie z mechanizmami oceny nowo powstających produktów czy usług finansowych oferowanych konsumentom. Z kolei kontrola zarządcza wydaje się zbiorczym instrumentem kontrolnym do zgodnego z przepisami prawa, skutecznego i efektywnego badania stanów i zjawisk procesów gospodarowania środkami publicznymi i nie "wymusza" w takim stopniu jak precyzyjniej uregulowany system kontroli wewnętrznej stosowania mechanizmów prognostycznych i naprawczych. W odniesieniu do kontroli zarządczej wydaje się również, że punkt regulacyjnej ciężkości normatywnej został ukierunkowany w większym stopniu na wzmocnienie zdolności ewaluacyjnej jednostek sektora finansów publicznych, na usprawnianie sektora publicznego poprzez wdrożenie nauk o zarządzaniu do systemu finansów publicznych, tak jak wcześniej uczyniono to w odniesieniu do 
kontroli wewnętrznej, i stworzenie systemu wewnętrznego zarządzania bankiem w prawie bankowym. Reprezentatywna jest także funkcja monitorowania ryzyka jako "rynkowego" elementu podlegającego urzeczywistnieniu $\mathrm{w}$ ramach celów kontroli zarządczej. W odniesieniu do kontroli zarządczej to głównie kierownik jednostki sektora finansów publicznych decyduje o tym, czy zawarte w komunikatach Ministra Finansów wzorce raportów będą podlegały doprecyzowaniu bądź uszczegółowieniu w zależności od specyfiki danej jednostki. Standardy kontroli zarządczej nie są sformalizowane, w przeciwieństwie do bardziej precyzyjnych i sformalizowanych standardów systemu kontroli wewnętrznej w prawie bankowym. System kontroli wewnętrznej $\mathrm{w}$ bankach jest ujęty $\mathrm{w}$ precyzyjnie określone ramy prawne $\mathrm{w}$ postaci nie tylko postanowień ustawy, ale również dyrektywy CRD IV oraz rozporządzenia CRR, a także rozporządzenia Ministra Finansów dotyczącego sposobu realizacji obowiązków i uprawnień związanych z systemem kontroli wewnętrznej w bankach. Tym samym w zakresie systemu kontroli wewnętrznej w prawie bankowym wskazać można, że podlega on bardziej formalistycznej regulacji, a mimo to, jak się wydaje, pozostawia bankom dużo miejsca na działalność samoregulacyjna, która uwzględniać musi wyznaczone ramy prawne. Strategie i rodzaje polityki bankowej muszą bowiem uwzględniać cele systemu kontroli wewnętrznej i znaleźć normatywne zakotwiczenie w art. 9-9f ustawy pr. bank. System kontroli wewnętrznej w bankach lepiej, choć nie idealnie, wpisuje się w tradycyjnie rozumiane pojęcie kontroli i jako precyzyjniej uregulowany wprowadza poczucie stabilności regulacyjnej. Z kolei pojęcie kontroli zarządczej trudno uporządkować w tradycyjnym podejściu kontrolnym, brak bowiem precyzyjnych standardów kontrolnych. Ponadto nastawienie na ewaluację działalności i autokontrolę oraz rozrost obowiązków związanych z raportowaniem, jak się wydaje, utrudnia mocne zakotwiczenie tej instytucji w prawie finansów publicznych. Zarówno jednak kontrola zarządcza, jak i system kontroli wewnętrznej w bankach stanowią bardziej procesy, systemy ciągłego zarządzania, które mocno ukierunkowane są na ex ante działania kontrolne oraz wczesne ostrzeganie, a także na bieżącą ocenę i ciągłe monitorowanie, które to elementy uzupełniane są działaniami naprawczymi i autokorekcyjnymi, rozwijającymi zdolności samoregulacyjne tak instytucji finansowych, jak jednostek sektora finansów publicznych. 


\section{THE INTERNAL CONTROL SYSTEM IN BANKS AND THE MANAGEMENT CONTROL INSTITUTION IN THE PUBLIC FINANCE SECTOR}

\section{S u m mary}

The aim of the study is to analyse two selected supervision institutions: the management control in the public finance sector and the internal control system in banks as examples of regulatory and supervision institutions, having regard to their functional similarities in the two areas of financial law: public finance law and financial market law, and banking law. The study was inspired by the desire to answer the question about the essence of internal control in public finance (management control), which shows, at least in terms of the control objectives, many elements characteristic for internal control systems operating in banks. The aim of the article is also to answer the question about the way of understanding the notion of "internal control" under the banking law and public finance law, its essence, objectives, functions, as well as the coherence of the understanding of the objectives and criteria of internal control in the widely understood financial law areas.

However, the research objective is also to show the differences between management control and internal control as supervision institutions, which due to the specificity of the controlled financial matters are separate and thereby allow to present the functions of control institutions related to the needs specific to particular areas of the broadly understood financial law and a multi-faceted approach to the most effective use of control institutions.

Keywords: financial control - internal control - management control - banking law - public finance law 